NBER WORKING PA?ER SERIES

CAPITAL MARKET INTEGRATION: ISSUES OF INTERNATIONAL TAXATION

Assaf Razin

Efraim Sadka

Working Paper No. 3281

\author{
NATIONAL BUREAU OF ECONOMIC RESEARCH \\ 1050 Massachusetts Avenue \\ Cambridge, MA 02138 \\ March 1990
}

This paper is part of NBER's research programs in International studies and Taxation. Any opinions expressed are those of the authors and not those of the National Bureau of Economic Research. 
NBER Working Paper \#3281

March 1990

\section{CAPITAL MARKET INTEGRATION: ISSUES OF INTERNATIONAL TAXATION}

\section{ABSTRACT}

The paper analyzes three issues in international taxation: (a) How the opening of the economy to international capital movements affects the size and structure of the fiscal branch of government: (b) Optimal restrictions on capital exports in the face of capital flight; and (c) The structure of taxes on mobile factors which emerges from international tax competitions and the gains from international tax harmonization.

\section{Assaf Razin}

Department of Economics

Tel Aviv University

Tel Aviv 69978

ISRAEL
Efraim Sadka

Department of Economics

Tel Aviv University

Tel Aviv 69978

ISRAEL 


\section{Introduction}

International capital market integration has become the subject of a major theoretical and practical interest in recent times. Policymakers are becoming more and more aware of the potential benefits accruing from such integration, which allows more efficient allocations of investment and saving between the domestic and the foreign market. In particular, with the prospective comprehensive integration of capital markets in Europe in 1992, some key policy issues arise. ${ }^{1}$

The financial, monetary and exchange rate management policy implications of capital market integration have been widely discussed in the context of the European Yonetary System (EMS); see, for instance, the survey by Iicossi (1988). However, capital market integration has also profound effects on the fiscal branch of each country separately and on the scope of tax coordination among them. These issues have not been dealt with extensively so far. ${ }^{2}$

One issue is the tax-induced distortions in the allocation of world savings and investment. In a world with international capital mobility, the equality between saving and investment need not hold for each country separately, but rather for world aggregate saving and investment. This separation brings out new issues of taxation in theory and practice. In a closed economy a tax on capital income drives just one wedge between the consumer-saver marginal intertemporal rate of substitution and the producer-investor marginal productivity of capital. In a vorld of open economies there are two more types of distortions 
which can be caused by capital income taxation: (i) international differences in intertemporal marginal rates of substitution, implying an inefficient allocation of world savings across countries; international differences in the marginal productivity of capital, implying that world investment is not efficiently allocated across countries.

The fundamental result of the theory of second best suggests that adding distortions to already existing ones may very well enhance efficiency and velfare. To put it differently, reducing the number of distortions in the economy may well lower vell-being. Thus, even though there are in general gains from international trade, some restrictions on free trade may be called for in a distortion-ridden economy.

The opening up of an economy to international capital movements affects the size and structure of the fiscal branch of its government. Capital flows influence both the optimal structure of taxes, on domestic and foreign-source income, and the velfare cost of taxation. As a result, the optimal size of government (the optimal provision of public goods) and the magnitude of its redistribution (transfer) policies are affected as vell.

Inother issue is capital flight. There is now substantial evidence that governments encounter severe enforcement difficulties in attempting to tax foreign-source income. Dooley (1987) estimates that in the 1980-82 time period as much as $\$ 250$ billion may be classified as capital flight by U.S. residents. Tanzi (1987) reports that tax experts were 
concerned that lowering the U.S. individual and corporate tax rates in the U.S. Tax Reform Act of 1986 would induce capital drain from other countries by providing a tax advantage to investments in the $\delta . S$. These concerns are based on an implicit assumption that the governments of these countries cannot effectively tax their residents on their U.S. income so as to wipe out the J.S. tax advantage. The issue of capital flight is even more relevant for developing countries. Cumby and Levich (1987) estimate that a significant portion of the external debt in developing countries is channelled into investments abroad through overinvoicing of imports and underinvoicing of exports. Dooley (1988) estimates that capital flight from a large number of developing countries amounts to about one-third of their external debt in the time period 1977-1984.

Finally, integration of capital markets brings up the issues of international tax coordination, harmonization and competition. There are two polar principles of international taxation: the residence (of the taxpayer) and the source (of income) principles. According to the first principle, residents are taxed on their world-wide income equally, regardless of whether the source of income is domestic or foreign. ${ }^{3}$ A resident in any country must earn the same net return on her savings, no matter to which country she chooses to channel her savings (the rate-of-return arbitrage). If a country adopts the residence principle, taxing at the same rate capital income from all sources, then the gross return accruing to an individual in that country must be the same, 
regardless of which country is the source of that return. Thus, the marginal product of capital in that country will be equal to the world return to capital. If all countries adopt the residence principle, then capital income taxation does not disturb the equality of the marginal product of capital across countries which is generated by a free movement of capital. However, if the rax rate is not the same in all countries, then the net returns accruing to savers in different countries vary and the international allocation of world savings is distorted.

According to the second principle, residents of a country are not taxed on their income from foreign sources and foreigners are taxed equally as residents on income from domestic sources. Now, suppose that all countries adopt this principle. Then a resident of country $\mathbb{H}$ earns in country $F$ the same net return as the resident of country $F$ earns in country F. Since a resident in country $\mathbf{H}$ must earn the same net return whether she channelled her savings to country $\mathbb{H}$ or to country $F$, it follows that residents of all countries earn the same net return. Thus, intertemporal marginal rate of substitution are equated across countries, implying that the international allocation of world savings is efficient. However, if the tax rate is not the same in all countries, then the marginal product of capital is also not the same in all countries. In this case the international allocation of the world stock of capital is not efficient.

1lthough there are two extreme principles of international 
taxation, in reality, countries adopt a mixture of the two polar principles. Accordingly, in practice, countries partially tax foreign-source income of residents and domestic-source income of non-residents, in which case both the international allocations of world savings and of world investments are distorted.

These issues are of particular relevance for Europe of 1992. The creation of a single capital market in the European Community raises the possibility of tax competition among the member countries, in the absence of a full-fledged harmonization of the income tax systems. Also, the possibility of capital flight from the EC to low-tax countries elsewhere has strong implications for the national tax structures in the EC. These developments renewed the interest among public finance and international finance economists in the issues of tax harmonization and coordination, tax competition, the international structure of taxation, etc. 4

\section{Restrictions on Capital Iobility}

Since there are distortionary taxes as part of an optimal fiscal program obviously the resource allocation is not Pareto-efficient: the intertemporal allocation of consumption, the leisure-consumption choice, and the private-public consumption tradeoffs are all distorted. Nevertheless, when the government can tax its residents on their foreign-source capital income, it is optimal to allow capital to move freely in or out of the country. That is, optimal policy ${ }^{5}$ requires an efficient allocation of capital between investment at home and abroad so 
that the marginal product of domestic capital is set equal to the world rate of interest (net of foreign taxes). Evidently, this is an open economy variant of the aggregate efficiency theorem in optimal tax theory (see Diamond and Yirrlees (1971), Sadka (1977) and Dixit (1985)).

Notice also that this production-efficiency result implies also that it is optimal to have a non differential tax treatment of foreign and domestic sources of income. One might argue that the investment efficiency result (i.e., equating the return on capital at home to the return on capital abroad via free international capital flows) is not valid when the government is concerned about financing its debt. For opening an economy to international capital flows will raise the domestic interest rate to the vorld rate. In such a case, a government which is burdened by an ongoing deficit incurs a higher interest cost of financing this deficit. In fact, it loses some of its monopsony power in the domestic capital market. It can then be argued in this case that the government may not wish to allow residents to invest abroad. However, in this case it can be shown that the investment efficiency result is still valid nevertheless. ${ }^{6}$ This is because the government can offset the cost of losing its monopsony power by an appropriate tax policy.

Suppose now that the government cannot effectively tax income from investment abroad. In this case, if the government allows unlimited exports of capital, then capital will flow out of the country up to the point where the net return on domestic investment equals the net return 
on investment abroad. This means that the marginal productivity of domestic capital will exceed the world rate of interest, so that the domestic stock of capital is too small. The mirror image of such an underinvestment in capital at home is an overinvestment in capital abroad.

Therefore, an interesting issue that arises in this context is whether it is now efficient from the society standpoint to restrict the exports of capital, and if so, how severe should the restriction be? One may ask, for instance, whether the restriction on exports of capital should bring the domestic capital stock all the way back to a level which is even higher than the level which is necessary for equating the marginal productivity required of domestic capital to the world rate of interest (i.e., an overinvestment in domestic capital). Furthermore, is it optimal to altogether ban capital exports when foreign-source income cannot be effectively taxed?

One can show that when the government cannot effectively tax foreign-source income, it should put severe restrictions on capital exports and bring the marginal product of domestic capital to a level which is even below the world rate of interest. The loss in the return to the private sector on their total investments (at home and abroad) due to the reallocation of capital from abroad to home is more than offset by the extra tax revenues on the income from the capital shifted to home accruing to the government.? 
Furthermore, if, under financial autarky, the marginal product of capital is sufficiently close to the world rate of interest then a total ban on capital exports is called for. The rationale for this result is straightforward. When the marginal product of capital is close to the world rate of interest there is very little gain for the society as a whole from investing abroad, because this gain is equal only to the difference between the marginal product of capital and the world rate of interest (although the private sector can still gain considerably from investing abroad because the net of tax marginal product of capital may be considerably below the world rate of interest. However, the government loses a significant amount of tax revenues from the outflow of capital. Therefore, in this case, it is not efficient to allow exports of capital.

\section{The Cost of Public Funds and the Size of Government}

The optimal size of government, or more precisely the optimal provision of public goods, must be determined by an appropriate cost-benefit analysis. Such analysis implies that the marginal cost of public funds must be equated to the marginal utility from public goods. To find the effect of liberalization in the international capital markets on the optimal quantity of public goods we discuss here the effect of such a liberalization on the cost of public funds in a small open economy. 
In calculating the cost of public funds, one must take into account the optimal response of the structure of taxation (on incomes from all sources) to the international capital market liberalization because the cost of public funds is derived from a process of a tax optimization. Therefore, we must also discuss the effect of liberalization on the structure of taxation. Of course, entangled with the structure of taxation is also the issue of the optimal size of income redistribution.

Suppose that the government can effectively tax income from capital invested abroad. In this case, a liberalization of the capital market is welfare improving. Therefore such a liberalization entails an income effect. Such an effect usually tends to increase the marginal utility of public goods. In addition it may lower the marginal cost of public funds because the government benefits directly from the liberalization as it taxes the increased amount of income from the capital invested abroad and can therefore lower the tax burden on domestic sources. Therefore, the income effect tends to increase the provision of public goods and the size of income redistribution. On the other hand, the liberalization may change the internal terms of trade (e.g., the real wage, etc.) and affect directly the cost of producing public goods. ${ }^{8}$ The effect of this change in the terms of trade on the cost of public funds and the size of government cannot a-priori be determined and should be examined empirically. 


\section{Feasible International Tax Structure}

Capital market integration between two large countries brings out the issue of the feasibility of their tax structures. When residents of one country invest in the other country, one must reckon with the possibility of tax arbitrage that may undermine the feasibility of integration.

To highlight this issue, consider a two-country world with perfect capital mobility. Denote the interest rates in the home country and the foreign country by $r$ and $r^{*}$, respectively. In principle, the home country may have three different tax rates applying to interest income:

(i) $t_{R D}$ - the tax rate levied on domestic residents on their domestic-source income;

(ii) $t_{\mathrm{BF}}$ - the tax rate levied on domestic resident on their foreignsource income

(iii) $t_{N R D}$ - the tax rate levied on non-residents on their interest income in the home country.

The foreign country may correspondingly have three tax rates which we denote by $t_{\mathrm{RD}}^{*}, \mathrm{t}_{\mathrm{RF}}^{*}$ and $\mathrm{t}_{\mathrm{NRD}}^{*}$. Furthermore, assume that these rates apply symmetrically for both interest earned and interest paid (i.e., full deductibility of interest expenses, including tax rebates).

A complete integration of the capital markets between the two countries (including the possibility of borrowing in one country in order to invest in the other country) requires, due to arbitrage possiblities, the fulfillment of the following conditions: 
(1)

$$
r\left(1-t_{B D}\right)=r^{*}\left(1-t_{\mathrm{NBD}}^{*}\right)\left(1-t_{\mathrm{BF}}\right)
$$

and

$$
r\left(1-t_{N R D}\right)\left(1-t_{B F}^{*}\right)=r^{*}\left(1-t_{B D}^{*}\right) \text {. }
$$

The first condition applies to the residents of the home country and it requires that they be indifferent between investing at home or abroad. Otherwise, they can borrow an infinite amount in the low (net of tax) interest rate country in order to invest an infinite amount in the high (net of tax) interest rate country. The second condition similarly applies to the residents of the foreign country.

Notice that unless

$$
\left(1-t_{\mathrm{BD}}\right)\left(1-\mathrm{t}_{\mathrm{BD}}^{*}\right)=\left(1-\mathrm{t}_{\mathrm{NBD}}\right)\left(1-\mathrm{t}_{\mathrm{BF}}^{*}\right)\left(1-\mathrm{t}_{\mathrm{NRD}}^{*}\right)\left(1-\mathrm{t}_{\mathrm{BP}}\right) \text {, }
$$

the only solution to the linear system of equations (1)-(2) is a zero rate of interest in each country:

$$
\mathbf{r}=\mathbf{r}^{*}=0 \text {. }
$$

Thus, some feasibility conditions on the structures of taxes must be met in order to satisfy (3) and yield a sensible world equilibrium.

Somewhat surprisingly, the two most common polar schemes of source-based or residency-based taxation are examples of feasible tax structures even when the two countries do not adopt the same scheme. 
Consider first the case in which both countries adopt the source-based tax scheme. In this case income is taxed according to its source, regardless of the residency of the taxpayer. This implies that

$$
\mathrm{t}_{\mathrm{RD}}=\mathrm{t}_{\mathrm{NRD}}, \quad \mathrm{t}_{\mathrm{RD}}^{*}=\mathrm{t}_{\mathrm{NRD}}^{*}, \mathrm{t}_{\mathrm{RF}}=\mathrm{t}_{\mathrm{RF}}^{*}=0,
$$

so that (3) is satisfied and we can have a world equilibrium with positive rates of interest.

Similarly, consider the case where both countries adopt the residence principle: income is taxed according to the residency of the taxpayer, regardless of its source. This implies that

$$
t_{\mathrm{RD}}=\mathrm{t}_{\mathrm{RF}}, \quad \mathrm{t}_{\mathrm{RD}}^{*}=\mathrm{t}_{\mathrm{RF}}^{*}, \quad \mathrm{t}_{\mathrm{NRD}}=\mathrm{t}_{\mathrm{NRD}}^{*}=0,
$$

so that, again, (3) is satisfied.

Next, consider the case in which one country adopts one tax scheme while the other adopts another one. Suppose, for instance, that the home country adopts the residence principle, while the foreign county adopts the source principle. In this case we have

$$
t_{\mathrm{RD}}=\mathrm{t}_{\mathrm{BF}}, \quad \mathrm{t}_{\mathrm{NRD}}=0 \text {, }
$$

(6)

$$
\mathrm{t}_{\mathrm{RD}}^{*}=\mathrm{t}_{\mathrm{NRD}}^{*}, \mathrm{t}_{\mathrm{RF}}^{*}=0,
$$


and, again, (3) is satisfied.

However, if the two countries do not stick to one of the two polar schemes, then (3) need not hold and no sensible world equilibrium exists. Suppose, for instance, that each country levies the same tax rate on its residents (irrespective of the source of their income) and also all non-residents investing in that country. In this case, we have

$$
t_{\mathrm{RD}}=\mathrm{t}_{\mathrm{RF}}=\mathrm{t}_{\mathrm{NRD}}, \quad \mathbf{t}_{\mathrm{RD}}^{*}=\mathrm{t}_{\mathrm{RF}}^{*}=\mathrm{t}_{\mathrm{NRD}}^{*}
$$

Hence, unless $\left(1-\mathrm{t}_{\mathrm{NRD}}\right)\left(1-\mathrm{t}_{\mathrm{NRD}}^{*}\right)=1$, which is just a sheer coincidence, condition (3) is violated.

Thus, some feasibility conditions on the tax structure are essential for a full capital market integration. Any mutually beneficial tax coordination or harmonization must satisfy the tax arbitrage condition (3).

\section{Tax Competition and Tax Harmonization}

International tax competition, or any fiscal policy competition for that matter, has major effects on the resource allocation across countries as well as within each country. For example, the aggregate (world-vide) level of savings as well as its cross-country composition may be distorted by such competition; similarly, the aggregate level of investment and its international allocation may become inefficient. In general, these effects on resource allocation can be decomposed into two 
elements. One concerns the indirect manipulation of the international terms of trade by various fiscal measures (other than explicit trade barriers such as tariffs and quotas) which is akin to the familiar "trade wars." The second element which received less attention concerns the international and domestic misallocation of resources that is generated by tax competition for given terms of trade.

This section focuses on the second of these two elements since the first one has been exhaustively studied and has become by now a textbook case. Consider therefore a stylized model in which tax competition within the group of countries that we analyze cannot affect their terms of trade. This can be accomplished by assuming that this group of countries is small relative to the rest of the world which effectively sets the international terms of trade.

Suppose first that fiscal policies are not harmonized internationally, so that the two countries are engaged in tax competition. However, some minimal degree of coordination among the two countries and the rest of the world prevail, so that they can effectively tax their residents on foreign-source income.

It can be shown that it is not optimal from the individual country's standpoint to tax foreigners on their income from capital invested in that country. ${ }^{2}$ Each one of the competing countries would tax its residents uniformly on their capital income from all sources, domestic as well as foreign. Thus, tax competition leads each country to adopt the residence (or world-wide) principle for the taxation of 
income from capital. Furthermore, there are no gains from tax harmonization.

In order to implement effectively a policy of taxing world-wide income, a considerable degree of coordination among countries is required, such as, for example, an exchange of information among the tax authorities, withholding arrangements, relaxing bank secrecy laws, etc. Suppose that the competing countries can reach such coordination which enables each to effectively tax its residents on their income from capital invested in the other country, even though they continue to engage in tax competition. However, assume now that they cannot tax the income from capital invested in the rest of the world, as they have no coordination (exchange of information, etc.), agreements with the rest of the world. This seems a rather interesting and realistic case which captures the essence of a problem hindering European integration, that of capital moving to low-tax countries in the rest of the world.

It can be shown that in this case that the rate-of-return arbitrage condition prevents each one of the competing countries from taxing its residents on their income from capital invested in the other country, even though their tax authorities can cooperate on such things as tax withholding, etc. This may explain why the EC dropped the idea of imposing a withholding tax on capital income. Tax competition leads to an extreme situation where no tax whatsoever is imposed by any one of the competing countries on capital income from any source. All of the 
tax burden falls on the internationally immobile factors (unskilled labor, land, etc.). Here again it can be shown that tax harmonization among our initially competing countries will yield no gains for them.

In conclusion, there are no gains from tax harmonization among competing countries which constitute just a fraction of the world economy, regardless of whether or not they are coordinated with the rest of the world. However, the first case in which there is some coordination with the rest of the world yields a higher level of welfare compared to the second case where no such coordination exists. These propositions underscore the important role of tax coordination. 


\section{FOOTNOTES}

In a recent paper $\mathbf{m i c o s s i}$ (1988) provides a succinct survey of the proposed institutional arrangements for the 1992 European integration. He writes:

"The European integration entails the elimination of restrictions and discriminatory regulations and administrative practices concerning: (i) the right of establishment and acquisition of participations by foreign institutions in domestic financial markets; (ii) permitted operations of foreign-controlled financial institutions; (iii) cross-border transactions in financial services. The first two items basically involve the freedom to supply services in EC national markets, the third, the freedom to move capital throughout the Community."

2 For an earlier discussion of the interaction among taxes, government consumption, and international capital flow, see Razin and Svensson (1983).

$3 \quad$ credit is given against taxes paid abroad on foreign-source income in order to avoid double taxation.

See, for instance, 11worth (1988), Bovenberg (1988), Giovannini (1988, 1989a, 1989b), Gordon (1986), Razin and Sadka (1989a, 1989b, 1990), Razin and Slemrod (1990), Sinn (1987) and Slemrod (1988).

5 See Razin and Sadka (1989a) and (1990).

6 See Razin and Sadka (1989a). 
7 See Razin and Sadka (1990).

8 See Razin and Sadka (1990).

$9 \quad$ See Razin and Sadka (1989b). 


\section{REPERENCES}

Alvorth, J.S. (1988), The Pinance, Investment and Taxation Decisions of Iultinationals, New York, Basil Blackuell.

Bovenberg, \. Lars (1988), "The International Effects of Capital Taxation: An Analytical Framework," mimeo, International Monetary Fund.

Cumby, Robert and Richard Levich, "On the Definition and Iagnitude of Recent Capital Flight," in Donald R.Lassard and John Villiamson (eds.) Capital Plight and Third Yorld Debt, Institute for International Economics, Vashington, D.C., 1987.

Diamond, Peer, A. and James Mirrlees, "Optimal Taxation and Public Production," Anerican Econonic Review, March and June, 1971, 8- 27 and $261-278$.

Dixit, Avinash, "Tax Policy in Open Economies," in Alan Auerbach and Martin Feldstein (eds.), Handbook on Public Econonies, Chapter 6, 314-374, North Holland, 1985.

Dooley, Iichael P., "Comment on the Definition and Iagnitude of Recent Capital Flight," by Cumby, Robert and Bichard Levich, in Donald R.Lassard and John Villiamson (eds.), Capital Plight and the Third Yorld Debt, Institute for International Economics, Vashington, D.C., 1987. 
"Capital Flight, a Response to Differences in Financial

Bisks," International Ionetary Fond Staff Papers, 35, No.3 (September 1988), 422-436.

Giovannini, Alberto, (1988), "International Capital lobility and Tax Avoidance," mimeo, Graduate School of Business, Columbia University. (1989a), "National Tax Systems vs. The European

Capital Market," Economic Policy, October.

(1989b), "International Capital lobility and

Capital-Income Taxation: Theory and Policy," mimeo, Graduate

School of Business, Columbia University.

Gordon, Roger, H. (1986), "Taxation of Investment and Savings in a

Vorld Economy," Anerican Econonic Review, 76, 1087-1102.

Iicossi, Stefano (1988), "The Single European larket: Finance,"

Banca Hazionale del Lavoro Quarterly Reviev, No.165, June, 1988, 217- 235 .

Razin, Assaf and Lars E.O.Svensson, (1983) "The Current Account and the Optimal Government Debt," Journal of International Ioney and Finance, 2(2), August, 215-224.

Razin, Assaf and Efraim Sadka (1989a), "Optimal Incentives to Domestic Investment in the Presence of Capital Flight," InF Vorking Paper, No. 90 . 
(1989b), "International Tax Competition

and Gains from Tax Harmonization," Vorking Paper No.37-89, Foerder

Institute for Economic Research, Tel-Aviv Oniversity. (1990), "Integration of the International

Capital Iarkets: The Size of Government and Tax Coordination," in Razin, Assaf and Joel Slemrod (eds.), International Ispects of Taxation, Oniversity of Chicago Press, 1990.

Sadka, Efraim, "A Note on Producer Taxation and Public Production," Reviev of Econonic Stadies, 44(2), June 1977, 385-387.

Sinn, H.Y. (1987), Capital Income Taxation and Resource Allocation, Amsterdam: North Holland.

Slemrod, Joel, (1988), "International Capital Yobility and the Theory of Capital Income Taxation," in H.Aaron and H.Galper, and J.Pechman, eds. Uneasy Compronise: Problens of a Hybrid Incone-Consumption Tax, Vashington, D.C.: Brookings Institution.

Tanzi, Vito, "The Response of Other Industrial Countries to the O.S. Tax Reform Act," Mational Tax Journal, 4(3), September 1987, 339- 355 . 